\title{
PROMOTION STRATEGY BY PALU CITY GOVERNMENT TO PULLING INVESTORS INTEREST IN PALU SPECIAL ECONOMIC ZONE
}

\author{
Muhammad Khairil \\ Faculty of Social and Political Sciences, Tadulako University, \\ Jl. Soekarno Hatta Km. 9 Palu, Central Sulawesi, Indonesia Phone: 082321216664. \\ Email: muh_khairil02@yahoo.com
}

\begin{abstract}
SEZ (Special Economic Zone) is one of the government's policy programs in national development planning. Reliable and excellent business and investment activities are the primary objectives of the Special Economic Zone policy. Promotion strategy in attracting investors interest continue to be enhanced by Palu City Government. The purpose of this research is to know the efforts made by Palu City Government in pushing Palu Special Economic Zone to potential investors. The method used is a qualitative method with case study approach. The results of this study indicate the interest to attract investors to do personal selling done by direct communication between the Government of Palu City and Central Sulawesi Provincial Government with potential investors. Finally constructed suggestions for the strategy of promotion of Special Economic Zones to attract potential investors to invest in Special Economic Zones. The contribution of this research is to provide insight on personal selling with potential investors done by the government of Palu and the Central Sulawesi province.
\end{abstract}

Keywords: Promotion, Strategy, Special Economic Zone

\begin{abstract}
Abstrak
KEK (Kawasan Ekonomi Khusus) adalah salah satu program prioritas pemerintah dalam perencanaan pembangunan nasional. Kegiatan bisnis dan investasi yang handal dan prima adalah tujuan utama dari kebijakan Kawasan Ekonomi Khusus. Strategi promosi dalam menarik minat investor terus ditingkatkan oleh Pemerintah Kota Palu. Tujuan penelitian ini adalah untuk mengetahui upaya-upaya yang dilakukan Pemerintah Kota Palu dalam mempromosikan Kawasan Ekonomi Khusus Palu kepada calon investor. Metode yang digunakan adalah metode kualitatif dengan pendekatan studi kasus. Hasil penelitian ini menunjukkan bahwa dalam menarik minat investor dilakukan personal selling yang dilakukan dengan komunikasi langsung antara Pemerintah Kota Palu dan Pemerintah Provinsi Sulawesi Tengah dengan calon investor. Akhirnya diperoleh saran untuk strategi promosi Kawasan Ekonomi Khusus sehingga dapat menarik minat calon investor untuk melakukan investasi pada Kawasan Ekonomi Khusus. Kontribusi penelitian ini adalah memberikan wawasan mengenai personal selling yang dilakukan oleh Pemerintah Kota Palu dan Pemerintah Provinsi Sulawesi Tengan dengan calon investor.
\end{abstract}

Kata kunci: promosi, strategi, Kawasan Ekonomi Khusus

\section{Introduction}

The globalization trend has increased sharply in the last decades of the 20th century. Major reformations took place within the world economy itself. The idea of a Special Economic Zone introduces a new concept of economic policy. This phenomenon has caused much debate among economists and others, because of its wide influence. Besides the pros and cons that arise due to differences in perceptions of the impact caused by the Special Economic Zone, there is a great hope for Special Economic Zones development, namely to improve national economy. This is also act as a foundation of Special Economic Zone in Palu City.

Palu City's Special Economic Zone is established through government regulation 
number 31 of 2014 on May 20th, 2014. On July 9th, 2017, the Special Economic Zone National Council has stated that the Palu City's Special Economic Zoneis ready to operate. Special Economic Zone of Palu City was inaugurated by Coordinating Ministerfor Economic Affairs, Darmin Nasution, as Chairman of the Special Economic Zone National Council on Wednesday, September 27th, 2017. It means that the Palu City's Special Economic Zone Area is ready to receive investment. In fact, the Palu City's Special Economic Zone has been cooperating with investors both from within and outside the country .

The total planned investment of the SEZ area development in Palu is to 1,7 trillion rupiahs with 1,500 acres land areas (Dewan Nasional Kawasan Ekonomi Khusus Republik Indonesia, 2017). Coordinating Minister for Economic Affairs, Darmin Nasution, said that in the effort of economic equality, the government encouraged the infrastructure development especially those that scattered throughout Indonesia through the development of Special Economic Zones, Industrial Areas, and the National Tourism Strategic Areas.

"This effort is aimed to accelerate development, especially outside of Java Island. Also, this policy is expected to reduce intra and inter-regional gaps," (Harian Kompas, 2017). Darmin continued, currently, there are 11 SEZ which has been established in Indonesia, one of them is the Special Economic Zone of Palu City.

Geographically, SEZ of Palu is also integrated with Pantoloan Harbour and strategic route of Indonesian Archipelagic Sea Lane. With these potentials, SEZ of Palu is projected to become the industry's strategic hub and logistics of the north-south corridor. Central Sulawesi Governor LongkiDjanggola said SEZ located in Central Sulawesi Province is the first area designed by the government as an integrated mining-processing industry and logistics center in Sulawesi region.

As the organizer of the Special Economic Zone, the city government of Palu undertook various promotional strategies, in this case, the promotion of the region's natural resources to attract the attention of the potential investors, both foreign investors and local investors. Target countries are Asia's fast-growing countries such as China and South Korea.

In order to attract potential investors to invest, it is necessary to design the right marketing mix that according to Philip Kotler (Cangara, 2014: 79) includes Product, Price, Place, and Promotion, (1) Product, is in form of goods or services produced by a business unit that wants to be marketed to meet the consumers needs; (2) Place, is the place used to distribute or displaygoods produced to attain consumer's attention; (3) Price, is the value of goods or services offered; (4) Promotion is the effort to get the consumer's attention through communication techniques. toBy promotional activities, there is a wrong assumption, i.e., spending cost for promotion rated as waste even though costs incurred for promotion must rate as an investment.

In addition to the marketing mix, promotion mix is also needed in order to design a communication strategy in order to attract investors. Traditionally, the promotion mix includes four elements: advertising, 
sales promotion, publicity / public relations, and personal selling (Morissan, 2014: 17). But George and Michael Belch (2015: 463) add two elements in the promotional mix, namely direct marketing, and interactive media.

According to Rogers (Cangara, 2014: 61), the communication strategy designed to change human behavior on a larger scale through the transfer of new ideas. Middleton (Cangara, 2014:61), a communication planning experts, added, a communication strategy is the best combination of all communication elements ranging from communicators, messages, channels, recipients and the effects are designed to achieve optimal communication goals.

Communication planning model commonly used in communication strategies is the AIDDA model. This model is linear and widely used in commercial whaling and marketing activities. The AIDDA model is short for Awareness, Interest, Desire, Decision, and Action (Cangara, 2014: 72).

(1) Awareness is the marketers or extension worker first step to be created for targeted audiences. Awareness here fixed on products, goods, or ideas offered. How far the target is aware of the benefits offered. For that matters, marketers or counseling officers must be able to show benefits offered to the target (Cangara, 2014: 72); (2) Interest is the appearance of target audiences interest for goods offered by marketers. Attention can only appear because what 's offered is new and not yet ever seen before. Besides of the benefits, interesting packaging can also cause interest of consumers (Cangara, 2014: 72); (3) Desire is the process that occurs after the attention arises to goods offered. On this stage, the buyer wishes the goods after weighing benefits or its usefulness. Marketers give psychiatric touch to consumer candidates with more persuasive means, so the desire arise and the consumer follows the suggestions if that offered as a form of idea from an extension worker (Cangara, 2014: 72.

Decision is actions taken by consumers, i.e. decided for having goods offered after weighing benefits and cost. The decision is based on the awareness process of benefits, attention to packaging and the price offered (Cangara, 2014: 72); (5) Action is done by the consumer after having the goods. It is related

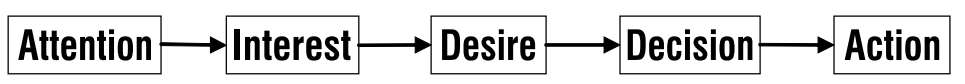

Picture 1. Elements of Promotional Mix

(Source: Morrison, 2014:17)

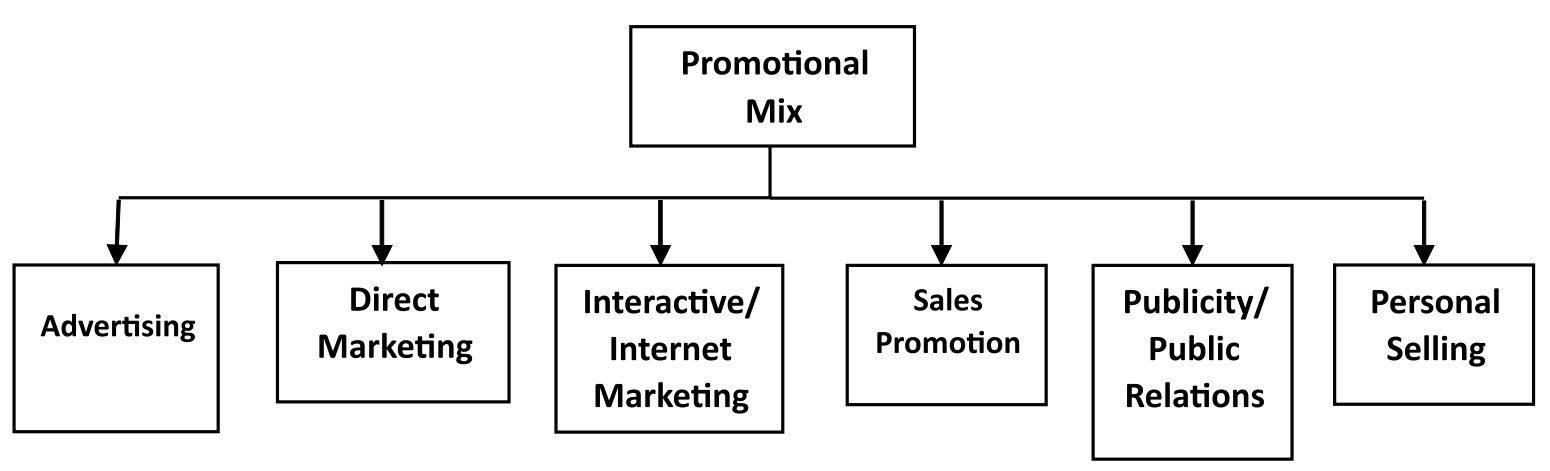

Picture 2. AIDDA Theory Model

(Source: Cangara, 2014:72) 
to the goods use as well as services that have been owned by consumers (Cangara, 2014: 72).

Most communicators use persuasive communication to influence public or someone. Persuasive communication should be done ethically. It takes honesty, truth, and candor (Cameron, Wilcox, Reber, \& Shin, 2013: 130). According to Aristotle (Suryanto, 2015:12), communication is built by three fundamental elements, namely the person who speaks, the material of the speech produced, and the person who listens to it. The first aspect is called a communicator or a persuader, which is the source of communication. The second aspect is the message. The third aspect is called communicant or persuadee, which is the recipient of the communication. $A$ persuader is a person or group of people who convey a message with the aim to influence the attitude, acceptance, and behavior of others, both verbally and nonverbally. In persuasive communication, the existence of a persuader at stake. Therefore, the persuaders must have a high ethos. Ethos is the value of one's self that is the aspect of cognition, affection, and conation (Suryanto, 2015: 12).

According to Thinking Public Relation: "Persuasion can be used to change or neutralize different (contrasting) opinions, crystallize positive opinions and attitudes and keep good and profitable opinions" (Cameron, Wilcox, Reber, \& Shin, 2013: 149). Persuasive communication is necessarily part of a communication strategy that can be used in persuading a person to do what the communicator wants. Palu City Government promotional efforts in attracting investors in Palu City's Special Economic Zone are not without flaws, and this research is done so the problems that arise in the implementation process of the strategy can be studied.

According to introduction above, the purpose of this research is to know the efforts made by Palu City Government in pushing Palu Special Economic Zone to potential investors

\section{Research Methods}

The method used in this research is a descriptive method with a qualitative approach to explaining the phenomenon that happened (Sugiyono, 2013:245). This research intended to look for detailed and factual information and topics about promotion efforts made by the Palu City's government to attract investors.

This research aims to understand the Promotion Strategies of Palu City's Special Economic Zone. Furthermore, the qualitative approach in this study tries to find and examine more about the factors that influence the promotion strategies so that it will lead to the location of the weaknesses and strengths of these factors. Thus, the promotional strategies that are implemented can then improved and ran effectively.

The analysis method used in this research is qualitative data analysis. Data analysis was performed at the time of the research, and after completion of the data As Miles and Huberman (Sugiyono, 2013:246) stated that qualitative data analysis is done interactively and continuously to the point where it is considered complete, so the data is saturated. The processes are data reduction, data presentation, and conclusion/verification. 


\section{Results and Discussion}

SEZ development aims to accelerate regional development and as a model of regional development breakthroughs for economic growth, including industry, tourism, and trade to increase employment. To accelerate the achievement of national economic development, it is necessary to increase investment through the preparation of areas that have economic and geostrategic advantages. The area is prepared to maximize industrial activities, exports, imports and other economic activities that have high economic values.

"Within three years, SEZ of Palu undertook several activities including the provision of infrastructure in the Special Economic Zone, human resources, and administrative control apparatus. With such conditions, SEZ of Palu is built within the area of 1.500 acres, is ready to operate to serve investors quickly," said the Governor of Central Sulawesi, Longki Djanggola, quoted from KOMPAS (Harian Kompas, 2017). Natural resource-based SEZ of Palu is expected to drive metal industry and increase the added value of superior agrocommodities in Sulawesi, such as cocoa, seaweed, and rattan.

To realize it, PT. Bangun Palu Sulteng (BPS) as BUPP (Badan Usaha Pembangunan dan Pengelola) or Construction Management Enterprise of Palu City's Special Economic Zone has established cooperation with PT. STM Tunggal Jaya. Both companies have established a joint venture to build and manage SEZ of Palu with investment value reached 7, 2 trillion rupiahs. The realization of investment in SEZ of Palu has been done by PT. Hong Thai
International by establishing a basic chemical industry factory based on pine resin processing with an investment value of Rp13,74 billion.

Three foreign investors who signed the agreement with BPST are PT. STM Tunggal Jaya, Tidfore Group of China, and Korea Western Power from South Korea. For domestic investors are PT. Pelabuhan Indonesia IV, PT. Wika Jabar Power, PT. Partagas Niaga and PT. PP Energi. This cooperation will cover the areas of the industrial estate (land management and project investment), infrastructure (water, electricity and transport / distribution), port service and logistics. "The average value of each investor reaches 5 million US dollars or around 65 trillion rupiahs, said President Director of PT. BPST Mulhanan Tombolotutu quoted from KOMPAS (Harian Kompas, 2017).

Currently, the company that has built a factory in SEZ of Palu, PT. Asbuton Jaya Abadi which is engaged in the asphalt industry has an investment value of more than 100 billion rupiahs with a workforce recruited as many as 120 people; PT. Hongthai International for the management of pine resin industry, with an investment value of about 15 billion rupiahs with a workforce of about 30 people; PT. Sofi Agro Industries, the coconut industry, with 1.389.000 US dollars investment value and the workforce of 625 people; PT. Agro Sulteng, which manages rubber industry with an investment value of 200 billion rupiahs and 100 people workforce; and PT. Artha Palu, which manages the essential oil industry with 50 billion rupiahs investment value and a workforce of 35 people (Harian Kompas, 2017). 


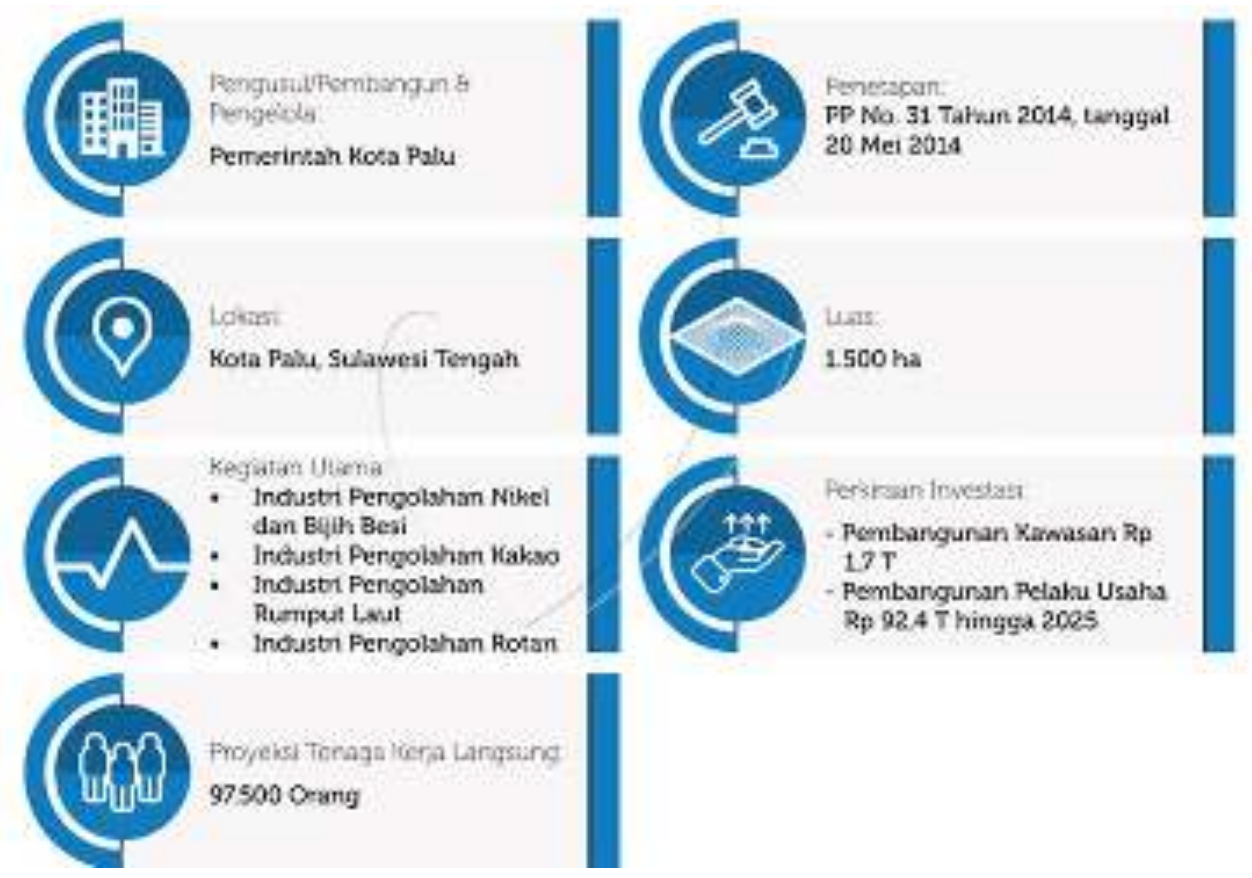

Picture 3. The Profile of Palu Special Economic Zone

(Source: Validnews.co, 2017)

The Palu Special Economic Zone focuses on increasing industrial activities. So what is trying to be driven by Palu City Government is an increase in industrial investors. It based on the natural resources of the Central Sulawesi Region which includes marine, plantation and forestry products such as cocoa, seaweed, and rattan.

One of the natural resources which are prioritized by Palu City Government to attract investor interest is rattan. Rattan is one of the many non-timber forest products owned by Central Sulawesi. There are five districts in Central Sulawesi Province which are the main rattan producing regions (Dewan Nasional Kawasan Ekonomi Khusus Republik Indonesia, 2017), Donggala, Parigi Moutong, Tojo Una-Una, Banggai, and Buol. Rattan, as one of the non-timber forest products, has become the source of increasing income for communities around the forests of Central Sulawesi Province. Not only that, but the production of rattan also cultivated the activities of the rattan industry for the processing of post-harvest rattan which absorbs a considerable amount of labor. So that rattan production in Central Sulawesi Province promises business opportunities for domestic and foreign investors to invest in Central Sulawesi Province especially in the field of rattan production.

Special Economic Zones encourage industrial growth to increase regional development and economy. So that abundant natural resources utilization and a distinctive commodity of the region to be the main attraction that should be highlighted. Palu City Government as the organizer of Palu Special Economic Zone promotes through communication channels (promotion mix): Integrating promotional tools between advertising in the form of brochures, posters, booklets and magazines; sales promotion in the form of exhibition, expo or event; and the 
last is personal selling conducted by direct communication between the government and investors.

There are eight steps to develop an effective communication programs according to Kotler \& Keller (2016: 179), i.e. identifying target audience, defining communication objectives, designing a message, choosing a communication channel, determining the total campaign budget, making decisions on promotional mix, measuring promotional results, managing and coordinating the integrated marketing communications process. Both Palu City Government and Central Sulawesi Provincial Government apply effective promotional strategies based on eight steps that stated above.

Palu Special Economic Zone target audiences are potential investors who are domestic or foreign entrepreneurs and companies. The communication process is done to persuade entrepreneurs and companies to invest in the Palu Special Economic Zone. Messages designed by the government include the availability of infrastructures, in the form of ports, to facilitate of raw materials and industrial products supply lines and the ease of investment in Special Economic Zones.

Communication Medias utilized by the government are printed media and audiovisual media. But the Palu City government also held face-to-face meetings with potential investors. It is considered the most effective way to persuade potential investors. The channels used are adjusted with the fundings for the promotion efforts. It becomes essential matter and acts as a base to make decisions regarding promotional mix. Because the promotion progress and outcomes should be measurable. The measurements are done by seeing an investment increase in Palu SEZ. The management and coordination of the integrated marketing communications process are handled directly by the Palu City government and Central Sulawesi Provincial Government utilizing Integrated Service Center or Pelayanan Terpadu Satu Pintu (PTSP).

Palu City Government promotes SEZ through advertisements based on natural resources of Central Sulawesi region through print media such as brochures, booklets, and magazines. Brochures, booklets, and magazines are the supporting mediums used in promoting SEZ of Palu. The government may apply the following strategies regarding the use of print media in marketing communications, (1) Packaging information through wording, coloring, and design; (2) Establishing awareness and product knowledge; (3) Utilization of compelling and exciting words; (4) Information presented must be clear and upto-date; (5) Highlighting product differences with competitors; (6) Informing development of facilities and infrastructure; (7) Alternative marketing advertising through online media; (8) Include an offer e.g. incentive .

From the results of interviews conducted by the author to one of the informants, Arifuddin, it is known that for the publication by the magazine, they are still dependent on the availability of budget from the agency. As for booklets, brochures, and posters are printed once a year in sufficient quantities. One obstacle to the development of advertising media is budget constraints. 
This should be minimized through the use of technology and efficient use of the budget.

Many companies still rely on one or two means of communication. This practice survives despite the breakdown of the mass market into small markets; each market requires its approach, a new kind of media burst and increased consumer sophistication. The wide range of communication tools, messages and audiences make communication imperative, so the company moves toward integrated marketing communications.

Palu City Government, in cooperation with the provincial government of Central Sulawesi, promotes Palu Special Economic Area by utilizing print medias and electronic medias. The print medias used were brochures that are made to be carried during official visits to other regions/countries. The goal is to promote the Palu Special Economic Zone so that potential investors know the important aspects of the Palu SEZ, especially related to the ease of investment.

In addition to the brochures, the Palu City government also uses two minutes long advertising video. The ad uses English as an international language and mainly done to reach out foreign investors. The advertisements feature the Palu Special Economic Zone as an industrial area.

Kotler \& Keller (2012: 500) stated that sales promotion is composed of a variety of services, including samples, coupons, premiums, demonstrations, contests, etc. The sales promotion efforts conducted by the city government in promoting Palu Special Economic Zone is to provide ease of investment permit for potential investors.
To actualize the ease of investment permit, the Government has an Administrator which is part of the Regional Council established in Palu SEZ to assist the Regional Councils in the implementation of SEZ. Administrators have a role to provide Integrated Service Center or Pelayanan Terpadu Satu Pintu (PTSP) that simplify the permit applications processes. With the Administrator presence, the potential investor does not need to run a convoluted process, because the Administrator has been given the delegation and authority from the institution / related agencies

Each media of communications has its characteristics, so it is important for the government to see which media is most appropriate because if it is wrong, it will lead to losses in the form of time, cost, and energy. Based on the analysis of the matrix on sales promotion, some strategies should be adopted by the government as follows: packaging promotional activities to be more interesting; establishing cooperative relations with investors; increasing the intensity of event participation; distributing other promotional media such as brochures; providing information needed by investors; promoting SEZ's superiority; and adding promotional media and then working with central government in promotional activities.

The second media promotion is sales promotion in the form of exhibition, expo or event. From the results of the research, the government has attended various events both national events such as the Sulteng Expo, Jakarta Expo, and Sail Tomini as well as an international event held in China, Australia, Dubai and various other countries. In 
2015, 13 investment related exhibitions and events were scheduled, consisted of 4 local exhibitions, eight domestic exhibitions outside the area and an exhibition in Japan. If you look at the promotional efforts through the event so far is quite optimal, viewed from the aspect of quantity, although substantially not showing any indicative impact on increasing investment. 2016 and 2017, the government promotes through cultural events, formerly referred to as the Festival Teluk Palu and now renamed Festival Pesona Palu Nomani, which has another purpose, besides celebrating Palu City anniversary, to attract investors both from domestic and foreign investors.

Participating in investment-themed events is a golden opportunity for the government to meet and communicate directly with potential investors. Also, the government is assisted by many parties, as has been done by the Central Investment Coordinating Board (BKPM) as a facilitator when promoting to Australia and also assistance from the Ministry of Economic Affairs when SEZ of Palu first launched and promoted.

An important aspect of foreign investment to have a positive spillover is a strong relationship by adjusting the needs of the domestic organization with the capabilities of foreign companies in SEZ. The pillars of inward investment policy to facilitate and encourage the blockage of technology transfer and skills include exposure, education, communication, and innovation (Richard \& Hunter, 2013).

Suryanto (2015: 332) defines that communications on Bisnis are an exchange of ideas, opinions, information, and orders that have a specific purpose that is presented personally or impersonally through symbols or signs. Business communication is also a process of exchanging messages or information to achieve the effectiveness and efficiency of work products within the organizational structure and system. There is an ongoing exchange of information in business communications. Also, there are some basic elements, namely (1) Purpose; (2) between communicators and communicants; (3) Ideas are the content of messages that vary depending on the purpose, situation, and condition of the organization; (4) Symbols used to convey messages.

Double contingency is also required in the process of information exchange. Double contingency is the system taken into account on how other systems outside of itself will receive the information that it produces. When Government's communication systems do not develop double contingency, other systems produce and reproduce information (Handaka, Wahyuni, Sulastri, \& Wiryono, 2017).

Governor Longki Djanggola, through cell phone message, said that the group consisting of Palu City Mayor Hidayat, President Director of PT. Bangun Palu Sulawesi Tengah, SEZ Palu management, Andi Mulahanan Tombolotutu and Central Sulawesi Region Provincial Economic Assistant Bunga Elim Somba arrived at Incheon, Seoul, on November 14th, 2017 at around 7:15 pm local time. In the city of Seoul, the delegation of the economic visits of the Provincial Government of Central 
Sulawesi, accompanied by officials from the SEZ National Council, was received by the Korean-Indonesian Partnership Council (Sulawesi Bisnis, 2017).

This economic visit is aimed to promote investment opportunities in Central Sulawesi, including the commencement of Palu Special Economic Zone operation. "We will meet and present our regional advantages and potentials in front of some investors from major corporations in South Korea, including property, energy and natural resources, marine and fisheries, shipbuilding and automobile assembly industries as well medicines," Longki said.

There are also Dong-Sung Corporation engaged in petrochemical and composite materials. Dong-Sung plans to expand its business in ASEAN and Asia in general, including Indonesia.Also, this commercial mission will also explore cooperation with SAMTAN Corporation engaged in energy and natural resources. The government's overseas visits are not merely personal selling which led to the agreements with the company, but also a comparative study regarding resource management natural resources.

Palu city government made a presentation to promote the potential of natural resources areas that can be utilized to build industry in the Palu City's Special Economic Zone. The presentation does not merely emphasize the issue of natural wealth, but also affordable human resources regarding wages. Based on Constitution No.561/806/ DISNAKERTRANDA-G.ST/2016 dated November 1st, 2016, the Central Sulawesi
Province minimum wage is IDR $1,807,775$ while the minimum wage of the district or municipality is IDR 2,056,750. This wage is considered low and still can be reached by investors, especially foreign investors.

The communication process should begin with a clear target audience in prospective of the company's products, current users, policymakers, or influencing parties: people, groups, particular communities or the general public. The target audience will greatly influence the communicator's decision about what to say, how to say it when to say it, where to say it and to whom it says it.

Many communications do not use sources outside of the company itself. Other communication strategies are either use famous or unknown people. Messages delivered by interesting or well-known sources can attract more attention and higher memory. The effectiveness of a message depends on the perceived level of expertise and trustworthiness of an endorser (Choudhury \& Mukherjee, 2014). Expertise is a specialized knowledge that communicators have to support claims. Trust is related to how efficient and honest the person is in the general public's eyes. Friends are more trustworthy than a stranger or salesmen, and people who are not paid to introduce products are more credible than those who are paid. Fondness for the spokesman describes the appeal of sources. Qualities such as honesty, humor, and naturalness make the preferred source.

One of the most difficult marketing decisions is to determine how much 
information that needs to be released for sale. Then the method of deciding the promotion budget as follows: affordable method, the percentage of sales method, competitive parity method, and objective and task method.

Public Relations and publicity are personal or nonpersonal activities aimed at protecting and strengthening the company image for employees or consumers, other firms, the government and the media via press kits, speeches, seminars, lobbying, etc. (Kotler \& Amstrong, 2012). The Central Sulawesi Government, the Government of Palu City and other agencies, work together in the publication of Palu City's Special Economic Zones. The goal is more of an informative purpose. So from the investor's standpoint, there is confidence and trust that the investment they are doing is known by the public. As for the potential investors, there will be an awareness that investments in Special Economic Zones provide benefits, as evidenced by the investments made by other companies.

The process, of course, requires media publications. The media used in the publication process is through websites such official www.palukota.go.id, sez. palukota.go.id, and http://kek.ekon.go.id. Furthermore, the publication process is also supported by media relations activities within Palu City. Online news websites that assist in the publication such as https:// www.suara.com, https://www.antaranews. com, https://kompas.com, http://republika. co.id, http://finansial.bisnis.com, http:// mediaindonesia.com, and http://sulawesi. bisnis.com. The government also made 6.6 minutes Palu Special Economic Zone profile video so that potential investors can see the appeal of Palu Special Economic Zone.

The strategies adopted by the government of Palu Ciry to make personal selling work efficiently are as follows: (1) to maintain good relations with investors; (2) provide insight to investors; (3) employing communicators that understand about Palu SEZ; (4) message are in the form of an investment invitation in Palu SEZ; (5) adjusting media messages delivery that coinciding with the characteristics of the investor; (6) maintaining two-way communication between stakeholders; (7) maintaining two-way communication between the government and investors; (8) using more varied media campaigns and reconfirm the potential investors.

Palu City Government should have adequate communication skills in communicating with investors. Excellent communicators are required to have a style of speech when conveying marketing messages, meaning that the communicators must use persuasive communication and informative communication to attract consumers (Anggraeni, Siswoyo, \& Nurfalah, 2014). Problems that arise are the language limitations between the Palu City Government with potential foreign investors. But this is probably not a big problem because the third party can mediate.

The process of communication regarding promotion to potential investors to invest in the Palu City's Special Economic Zones would require a specific strategy in the nego- 
tiations. Freeley (Effendy, 2015: 180) suggest a few things for a negotiator which he described as ethical standards as follows, (1) Should master the subject by preparing carefully and base the case on the evidence and arguments as well as possible; (2) Should present facts and opinions carefully; (3) Should mention the source of information; (4) Should welcome any disagreement with the good, and should maintain and foster debate as a means of making rational decisions.

The purpose of the negotiations is to reach the fulfillment of others. Reaching the fulfillment of others is one of the purposes of communication. Trying to try to let others do what they should be doing or to stop something we did not expect. Marvel and Schmitt (Littlejohn \& Foss, 2014: 178) using an exchange method theory as a basis for the fulfillment of their acquisition models. Someone would be obedient in exchange something that is provided by others: if there is suitability in price between what is given and what is received.

Palu City Government offers a variety of things that benefit a potential investor, such as the availability of natural resources and were able to meet the needs of industrial materials in a Special Economic Zone. It is also linked to the possibilities of limited facilities and infrastructure in the form of supply lines or the distance between the Special Economic Zones with source materials supplier, besides the availability of qualified and affordable human resources regarding wages. It is a point of interest that is offered in the promotion process undertaken by the Government of Palu City to potential investors.
In fact, acquisition fulfillment model can only run if there is sufficient source power and can give or withhold something to be desired by the other party, in this case, potential investors. This means Palu City government should have the power or the power required by the prospective investors, so they are willing to invest and meet the desires of the government in managing Special Economic Zones.

These three promotional tools applied by Palu City government in marketing communications must be maximized to Palu SEZ development messages can be delivered to investors. Lately, mass media are developed rapidly with the development of the information technology and new findings around the digital computer system. Their development makes the public consumption of information to increase. Thus, Palu City government needs to be aware that information is important commodities that need to be fulfilled.

Personal Selling processes include prospecting, reproach, approach, making the presentation, overcoming objections, closing the sale, and following up (Pride, et al., 2015: 477). Selections and assessments of prospects through a feasibility study of Special Economic Zone are conducted in cooperation between Palu City Government and Economic and Social Research Institute, Faculty of Economics and Business, University of Indonesia (LPEM FEB UI). This is done to measure the potential of Palu Special Economic Zone to attract potential investors and spark investment interest. After assessing the extent of the prospect next is to pre-approve. The pregovernment approach is to find out what is 
liked or what is the target of potential investors. By knowing all that is needed for the investors, Palu City Government finally did approach.

The government's approach is to visit. Visiting potential investors is done by Palu City government simultaneously with other activities outside the city. In other words, it was a compact, cost-saving trip. Through an approach with potential investors, the Palu City Government gets the approval of the potential investor for the next meeting with the presentation agenda. Presentations are conducted to provide an overview of the Palu SEZ. Usually, there will be objections raised by potential investors. Thus, to minimize these objections, Palu City Government has prepared various ease of investment offers as well as the availability of Natural Resources and Human Resources which is quite abundant and affordable. For 2017 and 2018, the government's target is to capture as many investors as possible so that the Special Economic Zone can be effective in 2019. So the Palu City Government is still opening the investment opportunity in Palu Special Economic Zone. The followup process is also in line with the increase of investors by maintaining good relations with investors and potential investors in Palu Special Economic Zone.

\section{Conclusion}

Regarding the promotion of Palu Special Economic Zone to potential investors, Palu City Government, in cooperation with the Provincial Government of Central Sulawesi, applied promotion mix that consisted of advertising, salespromotions, publicrelations and publicity, and personal selling. One of the strategies is carried through personal selling, namely through an official visit to foreign countries such as China and South Korea. Palu City government visitation is to do a presentation to other countries with potential investors such as China and South Korea. The advantages that can be obtained from Special Economic Zones investment are presented, attracting potential investors, and thus decided to invest in the Palu City's Special Economic Zone. Other efforts including events in the promotion. On occasions like this, Palu City government is taking advantages of the opportunities and meetings with the entrepreneurs to exchange opinions about the Special Economic Zone, various advantages, and charm offered by the Special Economic Zones.

Special Economic Palu area advertisements are still limited to brochures and video ads. It is suggested that at least the Palu City government put online banner/ ads on the existing websites. This kind of advertisement just needs a little cost because it is installed on site sites already owned by the Government of Palu.

The weakness of Palu City government's promotional strategies to attract investors to invest in the Special Economic Zones is just a matter of language barrier, mainly with foreign investors. Thus the negotiation process involves a third party as an intermediary regarding language. Furthermore, another problem is the lack of adequate information on the websites so that double contingency is not running optimally. The information contained on the website is very limited and rarely updated. In fact, if well-managed, investors can be interested just by seeing the websites. 


\section{References}

Anggraeni, N., Siswoyo, M., \& Nurfalah, F. (2014). Strategi Public Relations Dalam Mendukung Pemasaran Pembangkit Listrik Nasional. ASPIKOM, 206-220.

Cameron, G. T., Wilcox, D. L., Reber, B. H., \& Shin, J.-H. (2013). Public Relations Today: Managing Competition and Conflict. New York: Pearson.

Cangara, H. (2014). Perencanaan \& Strategi Komunikasi. Jakarta: Raja Grafindo Persada.

Choudhury, A. H., \& Mukherjee, D. K. (2014). Celebrity Endorsement and its Impacts on Students Buying Behaviour towards Personal Care Products. The International Journal of Business \& Management, 2(9), 22-29.

Dewan Nasional Kawasan Ekonomi Khusus Republik Indonesia. (2017). KEK Palu Resmi Beroperasi. Retrieved November 11, 2017, from http://kek.go.id/berita/2017/08/ KEK-Palu-Resmi-Beroperasi-145

Effendy, O. U. (2015). Dinamika Komunikasi. Bandung: Remaja Rosdakarya.

Handaka, T., Wahyuni, H. I., Sulastri, E., \& Wiryono, P. (2017). Perencanaan \& Strategi Komunikasi. ASPIKOM, 363-378.

Harian Kompas. (2017). 7 Perusahaan Teken MoU Bangun Industri di Kawasan Ekonomi Khusus Palu. Retrieved from http://regional.kompas. $\mathrm{com} / \mathrm{read} / 2017 / 05 / 17 / 06550711 / 7$. perusahaan.teken.mou.bangun.industri. di.kawasan.ekonomi.khusus.palu

Kotler, P., \& Amstrong, G. (2012). PrinsipPrinsip Pemasaran Ed 13 (13th ed.). Jakarta: Erlangga.
Kotler, P., \& Keller, K. L. (2012). Marketing Management 13. New Jersey: Pearson Prentice Hall, Inc.

Kotler, P., \& Keller, K. L. (2016). Marketing Managment. New York: Pearson.

Littlejohn, S. W., \& Foss, K. A. (2014). Teori Komunikasi. Jakarta: Salemba Humanika.

Morissan. (2014). Periklanan: Komunikasi Pemasaran Terpadu. Jakarta: Kencana.

Pride, W. M., Ferrell, O. C., Lukas, B. A., Schembri, S., \& Niininen, O. (2015). Marketing Principles 2nd Edition (2nd ed.). South Melbourne: Victoria Cengage Learning Australia.

Richard, J., \& Hunter, G. S. (2013). The impact area of special economic zones: the effect of FDI on technology and knowledge transfer for native American reservations - a study of employment, innovation and absorptive capacity. Global Business and Economics Research Journal, 1-28.

Sugiyono. (2013). Metode Penelitian Kuantitatif, Kualitatif dan $R \& D$. Bandung: Alfabeta.

Sulawesi Bisnis. (2017). Kawasan Ekonomi Khusus (KEK) Palu Ditawarkan ke Korea Selatan. Retrieved November 14, 2017, from http://sulawesi.bisnis.com/ $\mathrm{read} / 20171114 / 17 / 197047 /$ kawasanekonomi-khusus-kek-palu-ditawarkanke-korea-selatan

Suryanto.(2015). Pengantar Ilmu Komunikasi. Bandung: CV Pustaka Setia.

Validnews.co. (2017). KEK Palu Resmi Beroperasi. Retrieved November 17, 2017, from http://validnews.co/ KEK-Palu-Resmi-Beroperasi-Xst 